\title{
Sense of place predictors of perceived effects of a proposed island to mainland bridge on future experience
}

\author{
Jana Raadik Cottrell \\ Centre for Blue Economy of Tallinn University of Technology, Estonia \\ Colorado State University, USA \\ est.jana@gmail.com \\ Stuart P. Cottrell \\ Colorado State University, USA \\ stuart.cottrell@colostate.edu (corresponding author)
}

\begin{abstract}
This paper examines how Estonian and foreign tourists to Saaremaa Island perceive their future experiences in light of a bridge built from mainland Estonia to the island. A logistic regression resulted in six predictors (two demographic and four sense of place scales) of perceived future effects of a proposed bridge on future experience, accounting for $18 \%$ of the variance. The six predictors of perceived effects of a potential bridge to the mainland on future holiday experience to Saaremaa Island were nationality, education, socio-cultural context, memory, aesthetics, and wellbeing sense of place scales. Estonians were more positive about the bridge, which supports previous discussions of the essence of home and wellbeing. Wellbeing was the strongest and only positive predictor followed by educational level, memory, socio-cultural context, aesthetics, and nationality, which were all negative. Highlights allude to the predictive power of sense of place on perceived environmental change of development (bridge to island) to future experience among tourists.
\end{abstract}

Keywords: bridges, environmental change, islands, logistic regression, predictors, Saaremaa, sense of place

https://doi.org/10.24043/isj.86

(C) 2019-Institute of Island Studies, University of Prince Edward Island, Canada.

\section{Introduction}

Providing opportunities for high-quality tourist experiences is an important management objective for island environments, as it is at destinations where tourism is managed (Cole \& Hall, 2009). Islands as desired vacation spots face increased pressure on accessibility, and potential rapid development offered by fixed links (tunnels or bridges) broaden opportunities in terms of mobility (Baldacchino, 2007; Raadik Cottrell, 2010, 2017; Raadik, 2005). Islands with bridges tend to be more attractive to tourists, thanks to guaranteed access (Baldacchino, 2007). Yet, changes in the rate and tempo of transformation are observable in cases where bridges have been built, since the fixed links act as accelerators, hastening change (Giddons, 
2010). Bridged islands appear as new spatial configurations, facing tricky situations regarding management of the various and contradictory pressures imposed upon them (Baldacchino, 2007). Consequently, in many cases, forced control mechanisms (differentiated tolls, zoning, etc.) have created more structured places than before (Barthon, 2007). Mobility is polysemic, as well as spatial configurations created as an illusion to escape restrictions of social and terrestrial structures (Kaufmann, 2002).

The construction of bridges to islands relates to the realm of primary modernization (Beck, 1992). Promises of economic prosperity from such developments are accompanied by environmental and social threats. As Beck (1992, p. 140) suggests, the crisis of industrial society thriving for economic prospect lies in the illusion of risk management of its consequences: "threats are produced industrially, externalized economically, individualized juristically, legitimized scientifically, and minimized politically." Risk position is dependent on knowledge and availability of information (as well as often correlating with economic status) and thus relates to power and political ideology. Views on environmental risk in postcommunist societies are still largely influenced by the dominant ideology of a communist past of 'conquering nature' as well as a revival of primary modernization blindly adopted from a Western model in hopes for rapid economic growth. In a state of reflective modernization, perceptions of threat and related environmental concerns have changed social relations (Beck, 1992; Giddens, 1990). There is an impending conflict between primary and reflective modernization (Beck, 1991): the indisputable decisionmaking power assigned to political institutions versus political reflexivity based on social experience.

Mobility and places are inherently political, produced through performances of people involved in diverse practices of mobility (Bærenholdt \& Granas, 2008; Cresswell, 2006; Massey, 2005). 'Stretched out' social relations (Allen \& Hamnett, 1995) relate to claims made over places in terms of activity spaces (Massey, 1995) and require an understanding of spatial organizations of society. 'Tourismscapes' (van der Duim, 2007), with their rhizomatic (branching out) character, have contributed to a changed understanding and analysis of spatial concepts, such as place, centre, and periphery. As noted by Edensor (2006), sense of place is increasingly mobile and extending across space. Thus, discussions about identity and sense of place should reach further from settled, coherent notions of place to place as 'meeting-place' (Massey, 1995, 2001). Place identities are frequently contested as meanings of place vary across different groups and refer to the struggle over the material future of the place, based on rival interpretations of the past (Massey \& Jess, 1995). Massey and Jess (1995) suggest these battles most often occur between unequal forces, due to social, economic, cultural, environmental or political unevenness. Any of the contested claims are, however, made in a particular timespace context, which reflects constant change, thus those claims are subject to change as well.

Saaremaa, an Estonian island in the Baltic Sea, is in a continual state of transformation. Discussions to connect the island to the mainland by bridge continues. The bridge is viewed as part of a larger development plan: the first stage, a deep port on the west coast of the island, was constructed in 2007, after some years of debate over its environmental impacts. The port, planned initially for cruise ships and providing a layover for international cruisers as a side trip to St. Petersburg, Russia, is currently under development into a cargo harbor. As one of the few ice-free ports on the Estonian coast, together with the bridge, Saaremaa could become an attractive multiple-use transportation route. The time of island development under study was unique due to its transition from 50 years of a relatively closed community to a place 
with blurred boundaries, both physical and psychological (Raadik Cottrell, 2010, 2017; Raadik, 2005). The notion of the island as a relatively closed environment and society that is particularly sensitive to large developmental projects and expected change is expressed with concern among environmental organizations, local inhabitants and visitors (Raadik Cottrell, 2010). Expected changes are most likely to influence identity and sense of place; both concepts reflecting psychological aspects of experience (Relph, 1976; Twigger-Ross, 1996). Previous studies call for further investigation of changes in physical environment and threats to place identity with a focus on place disruption (Bott, 2000; Gibbons, 2010; Twigger-Ross, 1996).

\section{Purpose}

Pro-bridge sentiments on Saaremaa suggest the island place would maintain or increase as a competitive tourism destination if a bridge was built (Raadik Cottrell, 2010, 2017). Although visitor numbers have increased, the percentage of tourists in paid accommodation has stayed relatively stable over the past 10 years (2008-2018) (Statistics Estonia, 2019). Despite the importance of the tourism industry for the island, little research has focused on island visitor preferences and expectations of place and the development of their place meanings. This study examines the influence of nationality, education, and sense of place on perceived effects of a bridge to the mainland on future holiday experiences in particular as a follow up to a more general study of sense of place predictors of perceived environmental change effects on future holiday experiences to Saaremaa, Estonia (see Raadik Cottrell \& Cottrell, 2015). More specifically, the following hypotheses were tested:

$\mathrm{H}_{1}$ : There is a difference between foreign and domestic (Estonian) tourists on sense of place.

$\mathrm{H}_{2}$ : There is a relationship between nationality, education, sense of place on visitors' perceived effect of a bridge to the mainland on future holiday experience.

\section{Literature review}

\section{Sense of place and mobility}

Sense of place research is one possible approach to better understand setting qualities important to visitors and the connection to the psychosocial context of experience (Bott, 2000; Gross \& Brown, 2003; Williams \& Hall, 2002; Williams \& Stewart, 1998). As a multidimensional concept (Stedman, 2002), sense of place represents beliefs, emotions, and behavioral commitments specific to particular geographic settings (i.e. Estonian island in the Baltic Sea). Grounded in attitude theory, this understanding can better reveal complex relationships between the experience of a place and attributes of that place than approaches that do not differentiate between cognitive, affective, and conative domains (Jorgensen \& Stedman, 2001, 2006). In today's mobile world, new social scapes (actors and networks) are developed (Massey, 2005; van der Duim, 2007) across distinctions such as local-global and centre-periphery (Barenholdt \& Granas, 2008; van der Duim, 2007). This requires acknowledging that society is "performed through everyone's effort to define it" (Latour, 1986, p. 275). The making and re-making of places involves connections and mobility, as societies are acted upon over distances and at a distance, through social interactions and networks (Barenholdt \& Granas, 2008). Places are generated through a mix of planned 
activities and unpredictable meetings, spontaneous developments and political practices, resulting in undetermined outcomes in movement (Barenholdt \& Granas, 2008). Through movements, people link places together, stretch social relations as well as their 'habitus' (acquired patterns of thought, taste, and behavior constituting the link between social structures and social practice) over the space (Bourdieu, 1977; Edensor, 2006; King, 1995).

The modern mobilities of migration, commuting, and tourism feed into and produce each other (Williams \& Hall, 2002). 'Settled tourists' (Tuulentie, 2007) such as second homeowners become 'insiders' in a place. Relocating and commuting locals broaden their mobility, yet often acquire more spatial constraints than obtaining freedom (Kaufmann, 2002). Placing travel in the context of 'structured-confined' versus 'unstructured-infinite' (planned by time and event versus unplanned, spontaneous, and continuous) (Deleuze \& Guattari, 1987), mobility and place link and form specific space-time rhythms in relation to ground covered (Kaufmann, 2002). Desire for quick access to places for work and play has increased the need for infrastructural development. Yet "a 'freer' mobility is often the sign of people having assigned the degree of freedom that they have to their mobility rather than to something else" (Kaufmann, 2002, p. 58).

Research supports a positive connection between sense of place and residents' environmental concern for their communities (Bonaiuto, Breakwell, \& Cano, 1996; Kaltenborn, 1997, 1998; Kaltenborn, Andersen, \& Nelleman, 2009; Stedman, 2002; Vorkinn, \& Riese, 2001; WesterHerber, 2004). Connections of sense of place to rootedness or residential status have predominated the literature and raised questions of 'insiders' and 'outsiders' to a place, belongingness, personal as well as cultural identity, and the notion of 'home place' (Hay, 1998; Massey \& Jess, 1995; Raadik Cottrell, 2017; Relph, 1976). Attachment to a place is related to a concept of maintenance (Hay, 1998) and the daily or periodic physical contact necessary to develop and maintain a sense of place; otherwise sense of place becomes simply nostalgic in character (Raadik Cottrell, 2010). Yet, in many respects, the dichotomy between insiders' and outsiders' sense of place should be reconsidered in a highly mobile world of travelers. What about visitors' sense of place in general when 'the path is less traveled'?

\section{Measuring sense of place}

Sense of place measures in tourism research are limited (Gross \& Brown, 2003). Used to describe a site or location of special significance or meaning, the term 'sense of place' is commonly used across multiple disciplines including environmental design (Groat, 1984), environmental psychology (Stedman, 2002), geography (Cosgrove, 1989), and resource management (Kyle, Graefe, Manning, \& Bacon, 2003; Williams, Patterson, Roggenbuck, \& Watson, 1992), each with its own approach to operationalizing the construct (see Bott, 2000 for an in-depth literature review]. Much of the literature on sense of place in natural resources comes from leisure studies (see Gross \& Brown for an extensive literature review], centered on the combination of concepts of involvement (measure of attraction, self expression, and centrality to lifestyle) and place attachment (involving place dependence and place identity; see Williams \& Stewart, 1998) (Williams et al., 1992). These constructs are predominantly examined in the context of recreation (Gross \& Brown, 2003). To address the gap in the literature with respect to the integrated measurement of sense of place in quantitative research (Groat, 1995), Bott (2000) developed a set of psychometric domains, scales, and items to 
measure sense of place. This was used by Raadik Cottrell (2010) in tourism-related research. Bott's research supported the existence of four perceptual domains: two related to setting (physical and socio-cultural) and two related to individual/personal aspects (affective and functional individual), represented via 15 scales comprised of 90 sense of place items. The physical setting domain consists of three scales referring to natural settings, built environment, and the specific characteristics of each. The cultural setting domain consists of two scales including the inherent socio-cultural scale, referring to the historical, authenticity, and spirit of the place and the transactional socio-cultural scale with reference to a sense of belonging. The affective individual/personal domain includes five scales: aesthetic, existential, significance, memory, and transcendental. The functional individual/personal domain includes five scales as well: informational, prospect, refuge, safety, and wellbeing scales. Bott's work provides alternative constructs to the 'involvement' and 'place attachment' measures predominantly found in leisure research and more recently applied to tourism research (Gross \& Brown, 2003). 57 sense of place items adapted from Bott (2000) were used for the present study.

This paper examines how tourists to an island place perceive their future experiences to be affected by infrastructural changes (i.e. the building of a bridge from the mainland to the island). Sense of place psychometric scales are applied as predictors of visitor-perceived effects on future experience from a potential bridge connecting the mainland to a popular tourist island destination. Differences between foreign and Estonian tourists are examined as well on the sense of place scales.

\section{Study setting: Saare County, Estonia}

Saare is the westernmost county of Estonia, consisting of five major islands and numerous islets. Saaremaa is the largest of these islands with a population of 33,000 and has the only city in the county. Historically the area has been a border zone between West and East. In 1940, Estonia was annexed by the Soviet Union, and Saare County became a restricted border zone until the re-independence of the Estonian Republic in 1991. Fifty years of limited access contributed to the undeveloped coastline, ethnically homogenous population, and limited development pressure on natural resources, with the exception of moderate agricultural activities. The landscape of the islands changed during Soviet occupation due to the changed production modes (shift to collective farms), nationalization of land, and restricted private access to the sea. The islands, however, maintained a unique combination of traditional villages with small private farming and moderate-sized collective farmlands. With a population of $99 \%$ ethnic Estonians, the islands became an oasis of the nation, as the Soviet assimilation politics were not practiced in this border zone. Travel to the islands by non-resident islanders and other Estonians was prohibited without a special invitation from local inhabitants and was limited to two weeks to one month per invitation. Travel to the islands for those who had acquaintances or relatives there became more like a visit to the 'homeland' since the hosts were responsible for their guests. The modern lure of the island gained its potency from the restrictions, and the islands became a desired 'dreamland' for many Estonians. The passage of time on the islands and the security they provided were different from the 'restless' world outside. Local semi-cultural landscapes and customs became symbols of Estonia's past and were visualized in poems, paintings and popular songs. Lennart Meri, a well-known intellectual and humanist and first president of the newly independent country, wrote the 
book Silver White about the importance of the island place in European cultural history, which increased visits to the land of the 'mythical Thule Lake'. The 'Saaremaa Waltz', a song written by a local poet and made famous by a well-known Estonian singer during the era of Soviet occupation, echoed the beauty and resistance to alien powers and became a powerful representation of the place in attracting many Finnish tourists (Sooväli, 2004).

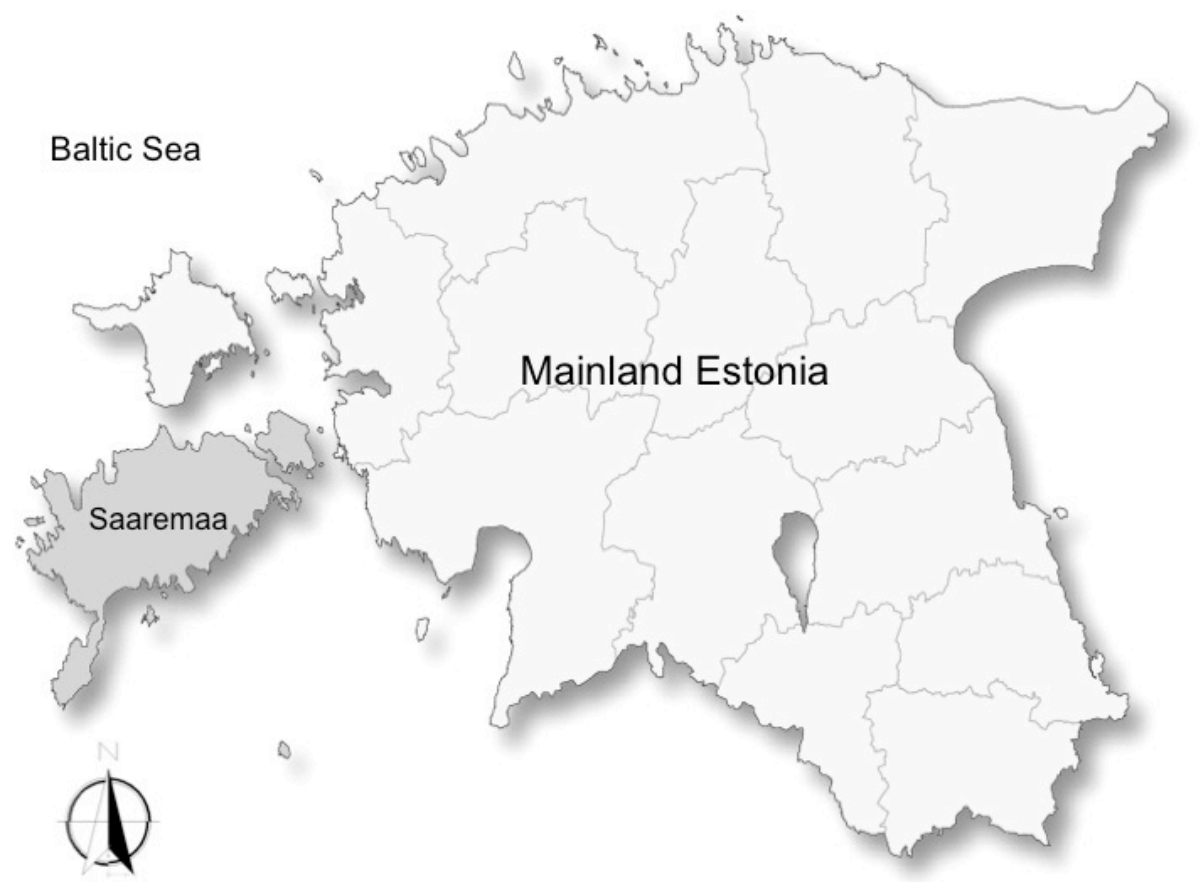

Figure 1: Saaremaa Island, Saare County, Estonia (shaded grey). Source: Raadik Cottrell \& Cottrell, 2015.

After the borders re-opened in 1991, Saaremaa became the top destination for inbound tourism as well as for international arrivals after Tallinn, the capital of Estonia, a Hanseatic city of world heritage importance. Since then, Saare County has become a desired summer destination under heavy developmental pressure. Increased spa tourism, high prices, and large summer events have changed the idyllic rural islands. Sightseeing spots are becoming more commercialized, and idealized tranquil landscapes are slowly turning into a "well-sold myth" (Kaur, Palang, \& Sooväli, 2004).

'An island where time rests' is a promise given to visitors by the tourism board while crossing the strait between the mainland and Saare County. However, there has been a dramatic increase in visitor arrivals, primarily via ferry (1.4 million passengers and 550,000 vehicle crossings in 2007, increasing to 1.7 million passengers and 735,000 vehicles in 2018) (Praamid, 2019). Access via ferry to the islands has raised several environmental, economic, and political concerns facing a contemporary Estonia, including a disturbed relationship between centre and periphery, the development of infrastructure as a promise of salvation from economic inequalities, and issues of mobility equated with personal freedom. Proposals for a bridge to the mainland originated in the 1930s (from the era of the first Republic) and have been anchored in political debates since the early 1990s. Since then, the bridge has been a source of political debate and electoral promise for many locals and domestic visitors desiring quick and stress-free travel (Raadik Cottrell, 2017). 


\section{Methodology}

Data for this study was collected from on-site surveys ( $n=487 ; 76 \%$ response rate) on the 30 minute ferry ride (80\% of surveys) between the mainland and island and at the Bishopric Castle in Kuressaare (20\%), a major tourist attraction on Saaremaa. Surveys (available in English, Estonian, and Russian) were conducted over 14 random days in July and August, 2007. Although data was collected in 2007, with results possibly limited to this data set, the paper illustrates the role of sense of place pertinent to enhanced understanding of perceptions of landscape change events, in this case a bridge to the mainland effect on perceived future experience.

\section{Research instrument}

A five-page, self-administered survey included questions regarding general activity and experience patterns on the islands, sense of place psychometric scales, recreational opportunities deemed important, and perceived future changes of place and the experience it would provide.

\section{Dependent variable}

Respondents evaluated how hypothetical changes in the island environment (i.e. decline of rural lifestyle, bridge to mainland, loss of traditional villages) might influence their future island experiences ('add to my enjoyment', 'no effect on my enjoyment', and 'detract from my enjoyment') (Kaur et al., 2004). The single item 'bridge to mainland' from the hypothetical change variables was used as the dependent dichotomous variable ('detract from my enjoyment' or 'add to my enjoyment') in the logistic regression for this paper.

\section{Independent variables}

'Sense of place' was examined using 20 items from the Raadik Cottrell (2010) study adapted from Bott (2000). Agreement scales (' $1=$ strongly disagree' to ' $5=$ strongly agree') were used to measure each sense of place item. Four summated scales replicated from Raadik Cottrell (2010) were supported by a reliability analysis: inherent socio-cultural scale with four items refers to the place as historic, authentic, enables a sense of history, and has a spirit of people; memory scale with six items refers to place as familiar, evokes strong memories, reminds one of a childhood place, has associations with some special place from the past, and evokes a sense of nostalgia; aesthetic scale with three items refers to place as beautiful, aesthetically pleasing, and generates positive sensory experience; wellbeing scale with eight items refers to place as safe, comfortable, serene, reassuring, revitalizing, peaceful, evoking a sense of comfort, and feels like being at home (see Table 1). Sense of place is assumed to positively or negatively influence perceived effects of a proposed bridge to the mainland on future holiday experience depending on the specific psychometric context of the sense of place scale (Kaltenborn, 1997, 1998; Vorkinn, \& Riese, 2001; Wester-Herber, 2004). The stronger the sense of place (i.e. memory of the place), the more negative the expected visitor-perceived effect of a bridge.

'Nationality' (Estonians and foreigners) as a demographic variable was included with the assumption that Estonians would have more positive perceptions related to the construction of the bridge, which has been promoted and mediated intensively as a symbol of progress (Raadik Cottrell, 2010), a logical step in the development and modernization of contemporary Estonia. Previous studies indicate that national identity plays a role in 
environmental perceptions: the stronger the national identity, the lower the ratings of perceived environmental threat (Bonaiuto et al., 1996).

'Educational level' was an expected predictor variable as it relates to a more critical evaluation of political claims made about progress in relation to the proposed bridge development (Beck, 1992), as well as a presumably greater level of environmental awareness.

Table 1: Reliability analysis of sense of place domains of visitors to Saare County Estonia.

\begin{tabular}{|l|l|l|l|}
\hline $\begin{array}{l}\text { Sense of Place Domains and } \\
\text { Composing Scale Items }\end{array}$ & $\begin{array}{l}\text { Item Total } \\
\text { Correlation }\end{array}$ & $\begin{array}{l}\text { Alpha if Item } \\
\text { Deleted }\end{array}$ & $\begin{array}{l}\text { Cronbach } \\
\text { Alpha }\end{array}$ \\
\hline Cultural Setting Domain & & & \\
\hline Inherent Socio-Cultural Scale & & & 0.64 \\
\hline Historic & 0.58 & 0.50 & \\
\hline Authentic & 0.40 & 0.62 & \\
\hline Has a spirit of people & 0.40 & 0.60 & \\
\hline Feel a sense of history & 0.40 & 0.60 & \\
\hline Memory Scale & & & 0.84 \\
\hline Familiar & 0.46 & 0.84 & \\
\hline Like I know it well & 0.55 & 0.82 & \\
\hline Feel a sense of nostalgia & 0.58 & 0.84 & \\
\hline Evokes strong memories & 0.65 & 0.81 & \\
\hline Reminds me of childhood place & 0.72 & 0.78 & \\
\hline Associate with special place from my past ${ }^{2}$ & 0.77 & 0.76 & \\
\hline Aesthetic Scale & & & 0.66 \\
\hline Beautiful & 0.52 & 0.53 & \\
\hline Aesthetically pleasing & 0.43 & 0.64 & \\
\hline Generates positive sensory experience & 0.49 & 0.54 & \\
\hline Wellbeing Scale & & & \\
\hline Safe & 0.41 & 0.80 & \\
\hline Comfortable & 0.61 & 0.77 & \\
\hline Serene & 0.52 & 0.79 & \\
\hline Reassuring & 0.60 & 0.78 & \\
\hline Revitalizing & 0.50 & 0.79 & \\
\hline A sense of comfort & 0.60 & 0.78 & \\
\hline Peaceful & 0.47 & 0.80 & \\
\hline Like being at home & 0.53 & 0.79 & \\
\hline Varables coded on a & & \\
\hline
\end{tabular}

${ }^{1}$ Variables coded on a 5 -point Likert type scale with $1=$ strongly disagree to $5=$ strongly agree.

${ }^{2}$ Items added to adapted items from Bott (2000).

Analysis strategy

Reliability analysis of the sense of place items was used to compute four sense of place psychometric scales (Table 1).

Independent sample t-tests were used to examine H1 the relationship between nationality and sense of place (with the assumption of differences in perception of place between domestic and international travelers) (see Table 2). For H2, sense of place indices and two demographic variables (nationality and educational level) were used as independent variables in a logistic regression to examine their predictive contribution to visitor-perceived 
effect of a bridge to the mainland on future holiday experience (dichotomous variable) (see Table 3). 190 respondents were included in the logistic regression since first-time visitors could skip the sense of place questions if they felt the place was not meaningful or due to missing values. Inter-correlations were checked between each predictor variable and the dependent variables to evaluate their individual contributions.

\section{Results}

The overall sample $(n=487)$ was predominantly married $(65 \%), 57 \%$ female, with a median age of $39.60 \%$ of the respondents were Estonians versus $40 \%$ foreigners. Of the foreigners, 16\% were Finns, 5\% Swedes, 5\% Germans, and the others came from 17 other countries. 54\% had an education at bachelor's level or above. $68 \%$ stayed a couple of days while $20 \%$ stayed a week. Transportation to the island was predominantly by ferry in a car (76\%) or bus (14\%) on the ferry, with $10 \%$ by some other means (plane $2 \%$ and $8 \%$ unknown).

Visitors' sense of island place

A reliability analysis was conducted to examine the internal consistency of the sense of place items for each of the composite indices. Cronbach alphas ranged from .64 (inherent sociocultural scale) to .84 (memory scale) (see Table 1). An independent sample t-test for hypothesis $1\left(\mathrm{H}_{1}\right)$ for the effect of nationality on four sense of place scales was used to examine differences among domestic and foreign visitors (Table 2).

Table 2: Means and differences between Estonians and foreigners on sense of place scales.

\begin{tabular}{|c|c|c|c|c|c|c|}
\hline \multirow{2}{*}{ Sense of Place Indices } & \multicolumn{2}{|c|}{$\begin{array}{l}\text { Estonians } \\
(\mathrm{n}=294)\end{array}$} & \multicolumn{2}{|c|}{$\begin{array}{l}\text { Foreigners } \\
(\mathrm{n}=193)\end{array}$} & \multirow[t]{2}{*}{$t$-value } & \multirow[t]{2}{*}{$\eta$} \\
\hline & $M$ & $S D$ & $M$ & $S D$ & & \\
\hline Inherent socio-cultural & 3.92 & 0.68 & 3.87 & 0.58 & 0.76 & .04 \\
\hline Memory $_{1}$ & 3.53 & 0.97 & 3.00 & 0.81 & $5.44^{\star \star \star}$ & .27 \\
\hline Aesthetic & 4.28 & 0.53 & 4.07 & 0.54 & $3.51^{\star \star \star}$ & .19 \\
\hline Wellbeing & 4.04 & 0.61 & 3.80 & 0.54 & $3.74^{\star \star \star}$ & .19 \\
\hline
\end{tabular}

Note. $\eta=$ effect size. $\quad{ }^{\star} \mathrm{p}<.05^{\star \star} \mathrm{p}<.01^{\star \star \star} \mathrm{p}<.001$

${ }_{1}$ Equal variances not assumed.

Estonians had significantly higher scores than foreigners for memory of place ( $M=3.53$ vs. $M=3.00)$, aesthetic evaluation $(M=4.28$ vs. $M=4.07)$, and for the individual wellbeing the place provides $(M=3.99$ vs. $M=3.78)$. The effect sizes, however, were minimal. Note: effect size emphasizes the size of the difference between Estonians and foreigners rather than confusing this difference with sample size (Vaske et al., 2002; Vaske, 2008).

\section{Perceived effect of proposed bridge on future island experiences}

Respondents rated how a bridge to the mainland as a hypothetical change in the island environment might influence their future island experiences ('detract from my enjoyment', 'no effect on my enjoyment', and 'add to my enjoyment'), which in essence represents a potential threat to the environment (Cole \& Hall, 2009; Kaur et al., 2004) that growth and development might present. Construction of the bridge was the most controversial perceived 
environmental change (Raadik Cottrell \& Cottrell, 2015). Approximately equal percentages of respondents rated the bridge as 'adding to their enjoyment' (32\%), having 'no effect on their enjoyment' (37\%), and 'detracting from their enjoyment' $(32 \%)(n=445)$.

An independent sample t-test (as a supplemental analysis) for the effect of nationality on perceived effects of a bridge on future experience found differences among domestic and foreign visitors. To establish a neutral point, the item was recoded with $-1=$ detracts from my enjoyment; 0 = no effect; and 1 = adds to my enjoyment. Estonians were more positive about the possible bridge than were foreigners (Estonians $M=.08$ versus Foreigners $M=-.12 ; t=$ 2.63; $\mathrm{p}<.01$ ) with a minimal effect size of .124 (Vaske, Gliner, \& Morgan, 2002).

Predicting future bridge to the mainland threat

A logistic regression (required for a dichotomous dependent variable) was conducted to determine predictors of perceived effects of a potential bridge to the mainland on future holiday experience for Hypothesis $2\left(\mathrm{H}_{2}\right)$. The single item 'bridge to mainland' was used as the dependent variable in the study to determine if a relationship between sense of place and the proposed bridge development existed. The item was recoded dichotomous $(0=$ detracts from my enjoyment; $1=$ adds to my enjoyment) with an even split between those who say the bridge detracts $(50 \% ; \mathrm{n}=140)$ and those who say it adds to their enjoyment $(50 \% ; \mathrm{n}=$ 141). The logistic regression for the model correctly classified $64 \%$ of the responses $(60 \%-$ detracts from my enjoyment, $61 \%$ - adds to my enjoyment) to explain $18 \%$ of the variance ( $8 \%$ contributed by the demographic variables and $10 \%$ by sense of place items), explained by the combined effect of the six independent variables on responses on the dependent variable - bridge detracts versus bridge adds to enjoyment. The model in general was a good fit to the data (Omnibus Test $\chi 2=27.95 . p<.000$, Hosmer and Lemeshow Test $\chi 2=4.97, p=.761$, Nagelkerke $\left.R^{2}=.18\right)$ (Vaske, 2008).

Table 3: Predictors of perceived bridge to mainland effect on future holiday experience.

\begin{tabular}{|l|l|l|l|l|l|}
\hline $\begin{array}{l}\text { Logistic Regression Model } \\
(\mathbf{n}=\mathbf{1 9 0})\end{array}$ & $\mathrm{B}$ & SE & $\begin{array}{l}\text { Wald } \\
\text { statistic }\end{array}$ & $\operatorname{Exp}(B)$ & $p$-value \\
\hline Demographic & & & & & \\
\hline Nationality & -.843 & .348 & 5.865 & .431 & .015 \\
\hline Educational level & -.360 & .135 & 7.115 & .698 & .008 \\
\hline Psychological/Sense of Place Indexes & & & & & \\
\hline Cultural Setting Domain & & & & & \\
\hline Inherent socio-cultural & -.588 & .295 & 3.974 & .555 & .046 \\
\hline Affective Individual/Personal Domain & & & & & \\
\hline Memory & -.489 & .227 & 4.636 & .613 & .031 \\
\hline Aesthetic & -.800 & .386 & 4.304 & .449 & .038 \\
\hline Functional Individual/Personal Domain & & & & & \\
\hline Wellbeing & .945 & .464 & 4.147 & 2.57 & .042 \\
\hline Omnibus Test $\chi 2=27.95 . p<.000 ;$ \\
\hline
\end{tabular}

Nagelkerke $R^{2}=.182$ indicating $18 \%$ of variance explained by the six variables in the logistic regression model. 
In the logistic regression model, both demographic variables and four sense of place scales were statistically significant predictors of individual perceptions of the impact the bridge would have on future holiday experience. Individual wellbeing $(\operatorname{Exp} B=2.57)$ was the strongest predictor of a positive evaluation of the bridge among the sense of place scales. (Note: In logistic regression, the odds ratio $(\operatorname{Exp} B)$ represents the constant effect of a predictor $\mathrm{X}$ (e.g. Nationality) on the likelihood that one outcome will occur on the dependent variable (e.g. a certain \% of respondents will correctly say the bridge detracts from their overall enjoyment; Vaske, 2008.) This is somewhat surprising as individual items constituting the wellbeing scale (see Table 1) such as safety, peacefulness, and serene would not typically be considered to have a positive association with large-scale infrastructural change such as a bridge to island, although items such as comfort and home may result in such a contradictory outcome. As expected, visitors with stronger place memory $(\operatorname{Exp} B=.613)$, inherent sociocultural $(\operatorname{Exp} B=.555)$, and aesthetic sense of place $(\operatorname{Exp} B=.449)$ scores rated the bridge as a detraction from their future place experience. As educational level $(\operatorname{Exp} B=.698)$ increased, negative perception of the bridge increased. For nationality $(\operatorname{Exp} B=.431)$, Estonians were in general more positive about the bridge than foreigners.

\section{Discussion and conclusions}

This study examined the predictive role of demographics and sense of place on visitor perception of bridge development on future holiday experience. Nationality influenced sense of place overall. Estonians had higher scores for memory, significance, aesthetics, and natural setting of place as well as the transcendental meanings and wellbeing of place than did foreigners. Yet, as with foreigners, there was some variation among Estonians about their island sense of place. This can be expected due to the diversity among Estonians (second homeowners, age, place of residence - rural countryside vs. capital city) and foreigners representing 21 countries.

Nationality affects how visitors perceive their future island experience with a bridge to the mainland. This can be attributed to the socio-cultural and political context of the potential bridge development. Estonians' exposure to political promises of improved 'home-space' via a bridge to the mainland and their negativity and resistance to environmental regulations imposed by the EU are partially explained by national identity (Bonaiuto et al., 1996; Raadik Cottrell, 2010, 2017). Such developmental change reminds Estonians of centralized decisions imposed by the former Soviet Union, raising issues of collective memory (Wertsch, 2002). The proposed bridge played a prominent role in the Estonian media over the course of several years and used to symbolize an intrinsic human right to easy access, representing 'an extension of the road', which could unite island space to the larger socio-economic space of Estonia (more specifically to a rapidly developing centre, the capital city of Tallinn) (Raadik Cottrell, 2010). Post-communist societies face changing value orientations towards nature, which affect perceptions of environmental risk (Koit, 2004). Sensitivity to environmental issues has a longer history in societies with an uninterrupted democratic process, accorded with the perception of higher individual responsibility and criticism towards the "predetermined route of progress" (Beck, 1991, 1992).

Differences in cultural memory play a role in the perception of landscape as well as changes in those environments (Brocki, 2004; Ingold, 1992; Knudsen, Metro-Roland, Soper, 
\& Greer, 2008). Estonians had higher scores for memory, aesthetic, and wellbeing sense of place scales than did foreigners. Theoretical discussions related to landscape perception stress the importance of aesthetics and mystery in the evolution of the very idea of national landscapes and identity (Cosgrove, 1985, 1989). Landscapes of national identity are comprehensible and significant and are related to aspects of memory and wellbeing. Island landscape and social environment symbolized 'home' for Estonians for many years, especially during the Soviet occupation. As a closed border zone, Saaremaa was a desirable place to visit, and memories of this period still remain. A survey conducted during the domestic travel fair 'Tourest' in Tallinn, administered by the local Saaremaa tourism board in February 2008 to the general public concerning perceived symbols of place, demonstrated the persistence of such symbolism. 'Home' or 'homeland' was the most common symbol, followed by symbols related to island landscape (juniper trees, sea, windmills). Notions such as 'home for everybody', 'a true Estonia', and 'escape from Estonia' were among the concepts related to this island place. Such statements map islands as a desired escape from mainland 'everyday reality', as popular holiday places (especially for celebrating the summer solstice, the most important symbolic event of the year), representing qualities of wellbeing sought out in meaningful places. For many domestic visitors, these landscapes relate to personal memories of childhood, as the majority of school excursions for students from the mainland go to Saaremaa. Notions related to childhood memories were also prevalent in the 2008 tourism board study.

'Home place' does not have a simple connection to memory and perceived effects from infrastructural change, such as a bridge to the mainland. Recollections of the past are not necessarily trapped in restorative nostalgia or easily explained by it (Boym, 2001; Smith, 1989). Estonians had higher scores on individual memory of the place than did foreigners yet were more positive towards the construction of a bridge, which would open the place to more rapid change via enhanced mobility. Emotional desires for easy access to 'home', to a place of individual significance and part of one's identity seem to mask perceptions of possible negative aspects of infrastructural change. Memory and meanings of place are bound to a specific time and space, and changes in place and corresponding disruptions in landscapes change perceptual identities over time (Ashworth \& Graham, 2005; May \& Thrift, 2001). Rooted memories accord with internalized mnemonic tools, so that "the mental map no longer relates to the topographic map" (Ashworth, 2005, p. 186).

\section{Implications}

Communication of the pros and cons of infrastructural change (bridge to mainland) with stakeholders (locals, tourists, tourism businesses, etc.) about the varying perspectives of foreign and domestic visitors may help alleviate conflicts and offer possible solutions based on a constructive dialog for responsible tourism development. In order to maintain and increase visitor satisfaction with the place, it is necessary to consider both foreign and domestic opinions about developmental issues. Such implications could be viewed in the wider context of tourism's role in Saaremaa's future as an island place. More importantly, there is a need for a more specific type of tourism development (e.g. nature-based tourism) that is more appropriate for environmentally sensitive areas such as islands. Building the bridge will have an undeniable impact on visitor flows and will affect the overall experience of the place, as supported by previous studies (Baldacchino, 2007; Terai, 1999). Yet, the chain reactions set off by building a permanent link such as a bridge are different case by case; previous studies 
show that islands connected to the mainland by fixed links have faced both declines and increases in visitor numbers over a period of time, decreases in local lifestyle, and negative or positive changes in landscapes due to increased developmental pressure (Baldacchino, 2007). In some cases, island place identity has been strengthened through desire to maintain distinctive communities via management actions such as strictly controlled visitor numbers (Baldacchino, 2007). Some linked island communities have a desire to reverse the way in which these fixed links affect tourism (Seraphin et al., 2018), for instance by introducing plans to demolish fixed links (Baldacchino, 2007; Gibbons, 2010).

From a methodological perspective, a new set of sense of place scales (Bott, 2000) were replicated and applied empirically as predictor variables. Obviously, not all of the psychometric scales would be applicable to this study or to any other particular study, but in the context of an overall examination of cultural memory and place identity, several scales were significant predictors, including memory of place and wellbeing. The development and application of a set of scales that are valid indicators of sense of place may be useful for evaluating places and experiences of places (Bott, 2000). Planning and managing for sustainable tourism may be enhanced by an understanding of what contributes to a positive or negative sense of place (Raadik Cottrell, 2010).

Theoretically, sense of place contributed slightly to perceptions regarding the effect of a bridge to the mainland effects on the quality of a future holiday. This has not been tested previously. Application of a new set of sense of place scales represented an attempt to step beyond the application of 'involvement' and 'place attachment' as the typical theoretical sense of place constructs used in the natural resource literature (Raadik Cottrell \& Cottrell, 2015; Wynveen et al., 2017; Wynveen, Schneider, \& Arnberger, 2018). Sense of place scales in this study provide an alternative approach to examining visitor-perceived experiences. Inherent socio-cultural memory plays a key role as a predictor of the bridge to island threat to visitor experience that illustrates the importance of culture for the experience of place for both foreign and domestic visitors.

\section{Limitations and future research}

Data was collected in 2007 primarily on a ferry (80\%), which is the major but not sole access point to the island. Since 2007, the number of visitors arriving to the island via cruise ships, private yachts and air transport has increased. Developing alternative access points to the island has been encouraged to cater to diverse markets (e.g. cruise tourism) and to meet contemporary tourists' expectations regarding island places.

This study highlights the necessity of recognizing the diverse needs and opinions of visitors concerning islands as a competitive tourism destination. These opinions point to possible conflicts between increased visitor numbers and the desired visitor experience. There is a need for more comprehensive longitudinal research to identify visitors' place assessment, perceptions of proposed changes, and expectations for future visits. Future research should include residents to identify possible discrepancies between different stakeholders in relation to future developments. 


\section{Acknowledgements}

The authors would like to thank the Saaremaa Ferries and the Bishops Castle Saaremaa for access to onsite data collection.

\section{References}

Allen, J., \& Hamnett, C. (Eds) (1995). A shrinking world? Global unevenness and inequality. Oxford: The Open University.

Ashworth, G.J. (2005). Imagining Newfoundlands. In G.J. Ashworth \& B. Graham (Eds), Senses of place: Senses of time (pp. 177-191). Farnham: Ashgate.

Ashworth, G.J., \& Graham, B. (Eds). (2005). Senses of place: Senses of time. Abingdon: Routledge. Baldacchino, G. (Ed.) (2007). Bridging islands: The impact of fixed links. Charlottetown: Acorn. Baldacchino, G., \& Spears, A. (2007). The bridge effect: a tentative score sheet for Prince Edward Island. In G. Baldacchino (Ed.) Bridging islands: the impact of fixed link (pp. 4765). Charlottetown: Acorn.

Bærenholdt, J.O., \& Granas, B. (Eds). (2008). Mobility and place: enacting Northern European peripheries. Aldershot \& Burlington: Ashgate.

Barthon, C. (2007). Bridge impacts on islands off the west coast of France. In G. Baldacchino (Ed.) Bridging islands: the impact of fixed links (pp. 219-235). Charlottetown: Acorn.

Beck, U. (1992). Risk society: towards a new modernity. London, Thousand Oaks, \& New Delhi: Sage.

Beck, U. (1991). Ecological enlightenment: essays on the politics of the risk society. M.A. Ritter (Trans.). Atlantic Highlands: Humanities Press International.

Bonaiuto, M., Breakwell, G.M., \& Cano, I. (1996). Identity processes and environmental threat: the effects of nationalism and local identity upon perception of beach pollution. Journal of Community \& Applied Social Psychology, 6, 157-175. https://doi.org/10.1002/(sici)1099-1298(199608)6:3\%3C157::aid-casp367\%3E3.3.co;2-n

Bott, S.E. (2000). The development of psychometric scales to measure sense of place. Unpublished dissertation. Colorado State University, Fort Collins.

Bourdieu, P. (1977). Outline of a theory of practice. Cambridge: Cambridge University Press.

Boym, S. (2001). The future of nostalgia. New York: Basic.

Brocki, M. (2004). Landscapes of memory: narratives of the past places. Paper presented at Culture, Nature, Semiotics: Locations IV, Tallinn.

Cole, D.N., \& Hall, T.E. (2009). Perceived effects of setting attributes on visitor experiences in wilderness: variation with situational context and visitor characteristics. Environmental Management, 44, 24-36. https://doi.org/10.1007/s00267-009-9286-8

Cosgrove, D.E. (1989). Geography is everywhere: culture and symbolism in human landscapes. In D. Gregory \& R. Walford (Eds) Horizons in human geography (pp. 118135). Totowa: Barnes \& Noble. https://doi.org/10.1007/978-1-349-19839-9 7

Cosgrove, D.E. (1985). Social formation and symbolic landscape. Totowa: Barnes \& Noble.

Cresswell, T. (2006). On the move: mobility in the modern Western world. New York: Routledge.

Deleuze, G., \& Guattari, F. (1987). A thousand plateaus. B. Massumi (Trans.). Minneapolis: University of Minnesota Press.

Edensor, T. (2006). Sensing tourist spaces. In C. Minca \& T. Oakes (Eds) Travels in paradox. remapping tourism (pp. 23-45). Lanham: Rowman \& Littlefield. 
Gibbons, M.S. (2010). Islanders in community: identity negotiation through sites of conflict and transcripts of power. Island Studies Journal, 5(2), 165-192.

Giddens, A. (1990). Consenquences of modernity. Cambridge: Polity.

Groat, L. (1984). Public opinions of contextual fit. Architecture, 59, 72-76.

Gross, M.J., \& Brown, G. (2008). An empirical structural model of tourists and places: progressing involvement and place attachment into tourism, Tourism Management, 29, 1141-1151. https://doi.org/10.1016/j.tourman.2008.02.009

Hay, R. (1998). Sense of place in developmental context. Journal of Environmental Psychology, 18(1), 5-29.

Ingold, T. (1992). Culture and the perception of the environment. In E. Croll \& D. Parkin (Eds) Bush base: forest, farm-culture, environment and development (pp. 39-56). New York: Routledge. https://doi.org/10.4324/9780203036129

Jorgensen, B.S., \& Stedman, R.C. (2006). A comparative analysis of predictors of sense of place dimensions: attachment to, dependence on, and identification with lakeshore properties. Journal of Environmental Management, 79(3), 316-327. https://doi.org/10.1016/j.jenvman.2005.08.003

Jorgensen, B.S., \& Stedman, R. (2001). Sense of place as an attitude: lakeshore property owners' attitudes toward their properties. Journal of Environmental Psychology, 21, 233248. https://doi.org/10.1006/jevp.2001.0226

Kaltenborn, B.P. (1998). Effects of sense of place on responses to environmental impact: a study among residents in Svalbard in Norwegian high Artic. Applied Geography, 18, 169-189. https://doi.org/10.1016/s0143-6228(98)00002-2

Kaltenborn, B.P. (1997). Nature of place attachment: a study among recreation homeowners in southern Norway. Leisure Sciences, 19, 175-189. https://doi.org/10.1080/01490409709512248

Kaltenborn, B.P., Andersen, O., \& Nelleman, C. (2009). Amenity development in Norwegian mountains: effects of second home owner environmental attitudes on preferences for alternative development options. Landscape and Urban Planning, 91(1), 195-201. https://doi.org/10.1016/j.landurbplan.2009.01.001

Kaufmann, V. (2002). Re-thinking mobility. Aldershot: Ashgate.

Kaur, E., Palang, H., \& Sooväli, H. (2004). Landscapes in change: opposing attitudes in Saaremaa, Estonia. Landscape and Urban Planning, 67, 109-120. https://doi.org/10.1016/s0169-2046(03)00032-x

King, R. (1995). Migrations, globalization and place. In D. Massey \& P. Jess (Eds) A place in the world? Places, cultures and globalization (pp. 5-40). Oxford: Open University.

Knudsen, D.C., Metro-Roland, M.M., Soper, A.K., \& Greer, C.E. (Eds) (2008). Landscape, tourism, and meaning. Burlington \& Aldershot: Ashgate.

Koit, M. (2004). Muhu saare elanikud sillaga ja sillata. Unpublished master's thesis, Estonian Institute of Humanities, Tallinn.

Kyle, G., Graefe, A., Manning, R., \& Bacon, J. (2003). An examination of the relationships between leisure activity involvement and place attachment among hikers along the Appalachian Trail. Journal of Leisure Research, 35(3), 249-273. https://doi.org/10.1080/00222216.2003.11949993 
Latour, B. (1986). The power of association. In J. Law (Ed.) Power, action and belief. London: Routledge \& Kegan Paul.

Massey, D. (2005). For space. London: Sage.

Massey, D. (2001). A global sense of place. In S.L. Roberson (Ed.) Defining travel: diverse visions (pp. 167-177). Jackson: University Press of Mississipi.

Massey, D. (1995). The conceptualization of place. In D. Massey \& P. Jess (Eds) A place in the world? Places, cultures and globalization (pp. 45-86). Oxford: Open University.Massey, D., \& Jess, P. (Eds) (1995). A place in the world? Places, cultures and globalization. Oxford: Oxford University Press.

May, J., \& Thrift, N. (Eds.). (2001). TimeSpace. London \& New York: Routledge.

Praamid (2019). Statistics. Praamid. https://www.praamid.ee/wp/statistics/

Raadik, J. (2005). Fixed link and island: a study of community identity on Saaremaa Island Estonia. Unpublished master's thesis, Wageningen University, Wageningen.

Raadik Cottrell, J. (2017). Island community: identity formulation via acceptance through the environment in Saaremaa, Estonia. Island Studies Journal, 12(1), 169-186. https://doi.org/10.24043/isj.11

Raadik Cottrell, J. (2010). Cultural memory and place identity: creating place experience. Doctoral dissertation. Ann Harbor: UMI Dissertation Publishing.

Raadik Cottrell, J., \& Cottrell, S.P. (2015). Sense-of-place influences on perceived environmental change effects on future holiday experiences to Saaremaa, Estonia. Scandinavian Journal of Hospitality and Tourism, 15(4), 425-446. https://doi.org/10.1080/15022250.2015.1024820

Relph, F. (1976). Place and placelessness. London: Pion.

Seraphin, H., Sheeran, P., \& Pilato, M. (2018). Over-tourism and the fall of Venice as a destination. Journal of Destination Marketing Management, 9, 374-376. https://doi.org/10.1016/j.jdmm.2018.01.011

Smith, G.E. (1989). Privilege and place in Soviet society. In D. Gregory \& R. Walford (Eds) Horizons in human geography (pp. 320-340). Totowa: Barnes \& Noble. https://doi.org/10.1007/978-1-349-19839-9 17

Sooväli, H. (2004). Saaremaa Waltz: landscape imagery of Saaremaa island in the 20th century. Unpublished doctoral dissertation, University of Tartu, Tartu.

Statistics Estonia (2019). Statistical database: Economy - Tourism, accommodation and catering. TR110: Capacity of accommodation establishments, accommodated tourists and nights spent by county. Statistics Estonia. http://pub.stat.ee/px-web.2001/Dialog/Saveshow.asp

Stedman, R.C. (2002). Towards a social psychology of place: predicting behavior from placebased cognitions, attitude, and identity. Environment and Behavior, 34(5), 561-581. https://doi.org/10.1177/0013916502034005001

Terai, S., \& Sato, Y. (1999). Study on planning to islands promotion in case of Nishi-Seto highway bridge construction: about the tourist industry in Ikuchi Island, Hiroshima Pref. Journal of Rural Planning Association, 18, 187-192. https://doi.org/10.2750/arp.18.18-suppl 187

Tuulentie, S. (2007). Settled tourists: second homes as a part of tourist life stories. Scandinavian Journal of Hospitality and Tourism, 7(3), 281-300. https://doi.org/10.1080/15022250701300249 
Twigger-Ross, C.L., \& Uzzel, D.L. (1996). Place and identity processes. Journal of Environmental Psychology, 16, 205-220. https://doi.org/10.1006/jevp.1996.0017

van der Duim, R. (2007). Tourismscapes: An actor-network perspective. Annals of Tourism Research, 34(4), 961-976. https://doi.org/10.1016/j.annals.2007.05.008

Vaske, J. (2008). Survey research and analysis: applications in parks, recreation, and human dimensions. State College: Venture.

Vaske, J., Gliner, J.A., \& Morgan, G.A. (2002). Communicating judgements about practical significance: effect size, confidence intervals and odds ratios. Human Dimensions of Wildlife, 7(4), 287-300. https://doi.org/10.1080/10871200214752

Vorkinn, M., \& Riese, H. (2001). Environmental concern in a local context: the significance of place attachment. Environment and Behaviour, 33(2), 249-263. https://doi.org/10.1177/00139160121972972

Wertsch, J.V. (2002). Voices of collective remembering. Cambridge: Cambridge University Press.

Wester-Herber, M. (2004). Underlying concerns in land-use conflicts: the role of placeidentity in risk perception. Environmental Science \& Policy, 7, 109-116. https://doi.org/10.1016/j.envsci.2003.12.001

Williams, A.M., \& Hall, C.M. (2002). Tourism, migration, circulation and mobility: the contingencies of time and place. In C.M. Hall \& A.M. Williams (Eds) Tourism and migration, new relationships between production and reproduction. Dordrecht: Kluwer. https://doi.org/10.1007/978-94-017-3554-4_1

Williams, D.R., Patterson, M.E., Roggenbuck, J.W., \& Watson, A.E. (1992). Beyond the commodity metaphor: examining emotional and symbolic attachment to place. Leisure Sciences, 14(1), 29-46. https://doi.org/10.1080/01490409209513155

Williams, D.R., \& Stewart, S.I. (1998). Sense of place: An elusive concept that is finding a home in ecosystem management. Journal of Forestry, 96(5), 18-23.

Wynveen, C., Schneider, I.E., Cottrell, S.P., \& Arnberger, A. (2017). Assessing place attachment measurement: a cross-site comparison in the United States and Germany. Society and Natural Resources, 30(11), 1389-1403. https://doi.org/10.1080/08941920.2017.1295499

Wynveen, C., Schneider, I.E., \& Arnberger, A. (2018). The context of place: issues measuring place attachment across urban forest contexts, Journal of Forestry, 116(4), 367-373. https://doi.org/10.1093/jofore/fvy001 
Jana Raadik Cottrell \& Stuart P. Cottrell 